\title{
Hepatocellular cancer
}

\author{
P. Godoy • H. M. Bolt
}

Published online: 24 December 2012

(c) Springer-Verlag Berlin Heidelberg 2012

In this issue, Rajagopal N. Aravalli from Minneapolis contributes a comprehensive review updating our knowledge on cellular and molecular mechanisms of hepatocellular cancer (Aravalli et al. 2013; this issue). Hepatocellular cancer (HCC) is the most common primary malignant tumor, with approximately 600,000 new cases occurring each year. Although most cases are in developing countries, the incidence is rising in Western countries, due to hepatitis $\mathrm{C}$, alcoholism and obesity. The normal liver lobule is composed of hepatocytes, sinusoidal endothelial cells, cholangiocytes, Kupffer cells, stellate cells and liverspecific natural killer cells, whereby complex cell-cell communications guarantee the maintenance of a functional architecture (Hoehme et al. 2010). Hepatocarcinogens or viral infections can cause abrupt changes in growth factor receptors, signaling factors or transcription factors and may initiate the multistep process of carcinogenesis, which differs between pericentral and periportal hepatocytes (Braeuning et al. 2010; Schreiber et al. 2011). Besides inflammation, the process of epithelial to mesenchymal transition (EMT) plays an important role that may be induced by an aberrant microenvironment and the extracellular matrix (Godoy et al. 2009, 2010). The review of Aravelli et al. addresses

- the pathophysiology of liver cancer, including the relevance of fibrosis and cirrhosis

- the relevance of the tumor microenvironment with the extracellular matrix and 'cancer-associated fibroblasts' as key components

P. Godoy · H. M. Bolt $(\bowtie)$

Leibniz Research Centre for Working Environment and Human Factors (IfADo), Leibniz Institut für Arbeitsforschung an der TU Dortmund, Ardeystrasse 67, 44139 Dortmund, Germany

e-mail: bolt@ifado.de
- cancer stem cells

- inflammation and oxidative stress

- cellular signaling networks

- the contribution of micro-RNAs

Liver carcinogenesis in rodents (Morita et al. 2011; Tawfeeq et al. 2012; Okabe et al. 2011) and humans (Fang et al. 2012) represents a cutting-edge topic in toxicology. The current state-of-the art review of Aravelli is definitely recommended to those interested in the field of HCC, in addition to anyone with a general interest in carcinogenesis.

\section{References}

Aravalli RN, Cressman ENK, Steer CJ (2013) Cellular and molecular mechanisms of hepatocellular carcinoma: an update. Arch Toxicol. doi:10.1007/s00204-012-0931-2

Braeuning A, Singh Y, Rignall B, Buchmann A, Hammad S, Othman A, von Reklinghausen I, Godoy P, Hoehme S, Drasdo D, Hengstler JG, Schwarz M (2010) Phenotype and growth behavior of residual beta-catenin-positive hepatocytes in livers of beta-catenin-deficient mice. Histochem Cell Biol 134(5): 469-481

Fang EF, Bah CS, Wong JH, Pan WL, Chan YS, Ye XJ, Tb Ng (2012) A potential human hepatocellular carcinoma inhibitor from Bauhinia purpurea L. seeds: from purification to mechanism exploration. Arch Toxicol 86(2):293-304

Godoy P, Hengstler JG, Ilkavets I, Meyer C, Bachmann A, Müller A, Tuschl G, Mueller SO, Dooley S (2009) Extracellular matrix modulates sensitivity of hepatocytes to fibroblastoid dedifferentiation and transforming growth factor beta-induced apoptosis. Hepatology 49(6):2031-2043

Godoy P, Lakkapamu S, Schug M, Bauer A, Stewart JD, Bedawi E, Hammad S, Amin J, Marchan R, Schormann W, Maccoux L, von Recklinghausen I, Reif R, Hengstler JG (2010) Dexamethasonedependent versus -independent markers of epithelial to mesenchymal transition in primary hepatocytes. Biol Chem 391(1):73-83 
Hoehme S, Brulport M, Bauer A, Bedawy E, Schormann W, Hermes M, Puppe V, Gebhardt R, Zellmer S, Schwarz M, Bockamp E, Timmel T, Hengstler JG, Drasdo D (2010) Prediction and validation of cell alignment along microvessels as order principle to restore tissue architecture in liver regeneration. Proc Natl Acad Sci USA 107(23):10371-10376

Morita R, Shimamoto K, Ishii Y, Kuwata K, Ogawa B, Imaoka M, Hayashi SM, Suzuki K, Shibutani M, Mitsumori K (2011) Suppressive effect of enzymatically modified isoquercitrin on phenobarbital-induced liver tumor promotion in rats. Arch Toxicol 85(11):1475-1484

Okabe K, Hayashi M, Yoshida I, Nishimura K, Fukushima N, Tsujichi T (2011) Distinct DNA methylation patterns of lysophosphatidic acid receptor genes during rat hepatocarcinogenesis induced by a choline-deficient L-amino acid-defined diet. Arch Toxicol 85(10):1303-1310

Schreiber S, Rignall B, Braeuning A, Marx-Stoelting P, Ott T, Buchmann A, Hammad S, Hengstler JG, Schwarz M, Köhle C (2011) Phenotype of single hepatocytes expressing an activated version of beta-catenin in liver of transgenic mice. J Mol Histol 42(5):393-400

Tawfeeq MM, Hayashi H, Shimamoto K, Suzuki K, Shibutani M, Inokuma H, Mitsumori K (2012) Mechanistic study on liver tumor promoting effects of flutamide in rats. Arch Toxicol 86(3):497-507 